\title{
Impacts of fisheries on the Critically Endangered humpback dolphin Sousa chinensis population in the eastern Taiwan Strait
}

\author{
Elisabeth Slooten ${ }^{1, *}$, John Y. Wang ${ }^{2,3}$, Sarah Z. Dungan ${ }^{2,3}$, Karin A. Forney ${ }^{4}$, \\ Samuel K. Hung ${ }^{2,5}$, Thomas A. Jefferson ${ }^{6}$, Kimberly N. Riehl ${ }^{2,3}$, Lorenzo Rojas-Bracho ${ }^{7}$, \\ Peter S. Ross ${ }^{8,9}$, Ashley Wee ${ }^{3}$, Robin Winkler ${ }^{10}$, Shih-Chu Yang ${ }^{11}$, Chaolun A. Chen ${ }^{12}$ \\ ${ }^{1}$ Otago University, Dunedin 9016, New Zealand \\ ${ }^{2}$ FormosaCetus Research \& Conservation Group, Thornhill, Ontario L4J-7X1, Canada \\ ${ }^{3}$ Trent University, Peterborough, Ontario K9J 7B8, Canada \\ ${ }^{4}$ Protected Resources Division, Southwest Fisheries Science Center, NMFS, NOAA, Santa Cruz, California 95060, USA \\ ${ }^{5}$ Hong Kong Cetacean Research Project, Lam Tin, Kowloon, Hong Kong 999077, SAR \\ ${ }^{6}$ Clymene Enterprises, Lakeside, California 92040, USA \\ ${ }^{7}$ Coordinación de Investigación y Conservación de Mamíferos Marinos, \\ Instituto Nacional de Ecología y Cambio Climático (INECC), Ensenada, Baja California 22860, Mexico \\ ${ }^{8}$ Fisheries and Oceans Canada, Institute of Ocean Sciences, Sidney, British Columbia V8L 4B2, Canada \\ ${ }^{9}$ Eastern Taiwan Strait Sousa Technical Advisory Working Group (ETSSTAWG), Sidney, British Columbia V8L 3Y3, Canada \\ ${ }^{10}$ Winkler Partners, Attorneys at Law, Taipei 100, Taiwan \\ ${ }^{11}$ FormosaCetus Research \& Conservation Group, Hualien City, Hualien County 970, Taiwan \\ ${ }^{12}$ Biodiversity Research Centre, Taiwan International Graduate Program (TIGP) Biodiversity, Academia Sinica, Nangang, Taipei 115, Taiwan
}

\begin{abstract}
Biological and fisheries data were analysed to assess the impact of fisheries mortality on a Critically Endangered subpopulation of $<100$ humpback dolphins Sousa chinensis in the eastern Taiwan Strait (ETS). Substantial interactions between ETS S. chinensis (hereafter Sousa) and fishing gear are known to cause dolphin mortality. In 2009, a total of 6318 motorised fishing vessels were operating from ports within Sousa habitats. An average of 32 fishing craft per kilometre was observed along a $200 \mathrm{~km}$ stretch of Sousa habitat. Based on a photo-identification catalogue, $>30 \%$ of the ETS Sousa subpopulation exhibited injuries caused by fishing gear. Three individuals were photographed with fishing gear attached to their bodies, and 1 dolphin was found dead with fresh injuries caused by fishing gear. To ensure recovery of ETS Sousa, mortality due to human causes should be reduced to $<1$ individual every 7 yr. Fisheries bycatch is the most serious threat to these dolphins and needs to be eliminated as soon as possible to avoid extinction. Preventing the use of trammel nets, other gillnets and trawling throughout their habitat would be the single most effective conservation measure for ETS Sousa in the short term. Other fishing methods are available, and using the most selective, sustainable fishing methods available will benefit not only dolphins but also fish stocks, seabirds and other species, as well as the fishing industry, which depends on these species for its long-term viability. However, in the short term, there are costs associated with switching to more selective fishing gear.
\end{abstract}

KEY WORDS: Fisheries impacts - Eastern Taiwan Strait - Critically Endangered · Bycatch · Indo-Pacific humpback dolphins

\section{INTRODUCTION}

A narrow, shallow band of water of approximately $200 \mathrm{~km}$ in length along the west coast of Taiwan
(Fig. 1) is home to an isolated and Critically Endangered (Reeves et al. 2008) subpopulation of $<100$ Indo-Pacific humpback dolphins Sousa chinensis (Wang et al. 2007a). Frequenting shallow inshore 
waters $(<30 \mathrm{~m}$ deep; Wang et al. 2007a), these dolphins inhabit some of the most industrialised coastal areas in the world (Ross et al. 2010). The 23 million people of Taiwan live in an area of just over $36000 \mathrm{~km}^{2}$ (Taiwan Yearbook 2012 www.gio.gov.tw/taiwanwebsite/5-gp/yearbook/), giving an average population density of $>637$ people $\mathrm{km}^{-2} ; 90 \%$ live in counties that border the west coast (Ross et al. 2010, Taiwan Yearbook 2012, www.gio.gov.tw/taiwanwebsite/5-gp/yearbook/). Dolphins relying exclusively on this nearshore environment are highly vulnerable to impacts associated with human activities.

The very small population size, coupled with a growing recognition of its vulnerability to anthropogenic threats, culminated in a 2008 listing of eastern Taiwan Strait (ETS) Sousa chinensis (hereafter Sousa) as 'Critically Endangered' by the IUCN Red List of Threatened Species (Reeves et al. 2008). This literally means that they are 'facing an extremely

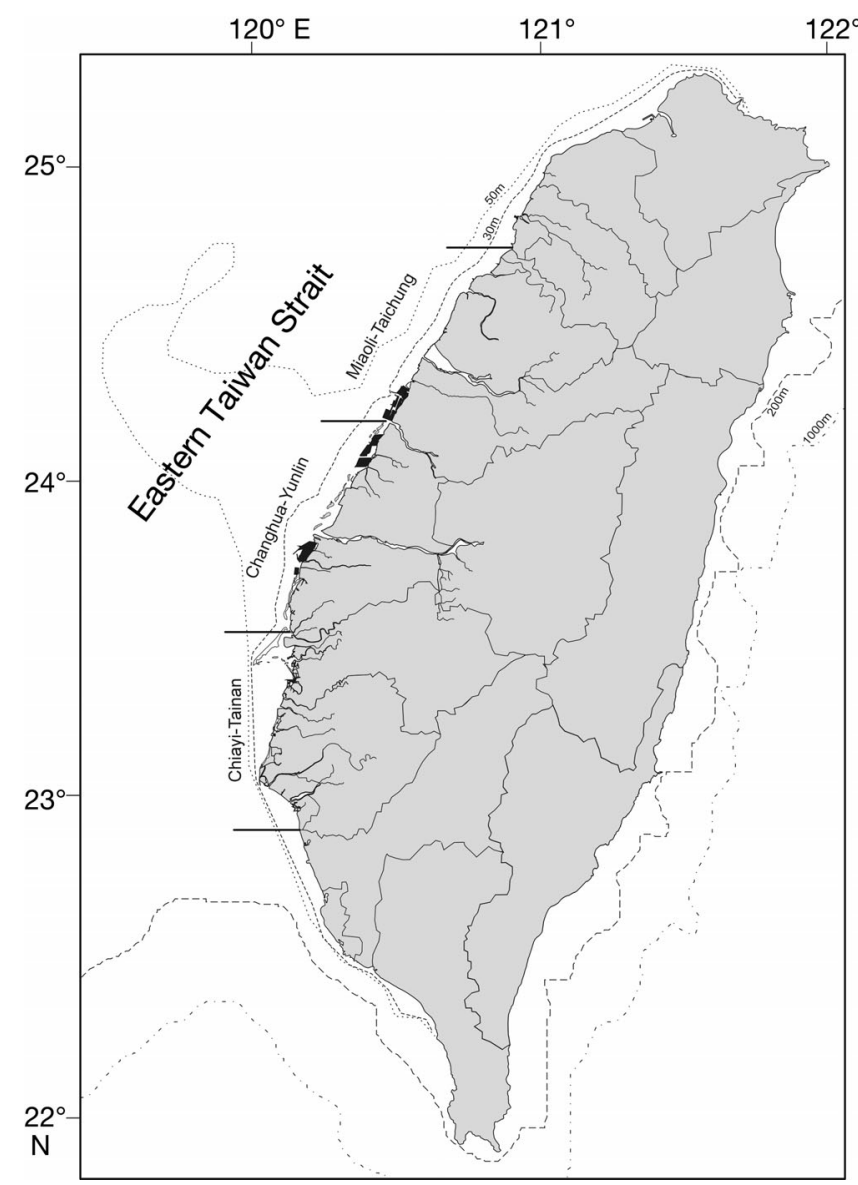

Fig. 1. Eastern Taiwan Strait (ETS) humpback dolphins Sousa chinensis (hereafter Sousa) are found in waters $<30 \mathrm{~m}$ deep, offshore of the counties indicated on the map: Taichung in the north to Tainan in the south. Three survey areas, each comprising 2 counties, are indicated on the map high risk of extinction' (IUCN 2001). Five major threats underscore the conservation imperative for these dolphins; these are discussed in more detail elsewhere (Wang et al. 2004, 2007b, Ross et al. 2010, Dungan et al. 2011). Briefly, habitat loss has taken the form of land reclamation for industrial, aquaculture and agricultural development. Industrial, urban and agricultural pollution introduces countless chemical and biological agents into coastal waters, where they may affect the dolphins directly, as well as the quantity and/or quality of dolphin prey and their habitats. Freshwater flow into the estuaries that comprise important dolphin habitat along the coast has decreased by as much as $80 \%$ (Ross et al. 2010). Noise and disturbance associated with ongoing shipping, fishing, coastal construction/development, and seismic and military activities permeate the water column. Finally, fishing nets (including gillnets, trammel nets and trawl nets) employed by an active fisheries sector threaten dolphins with injuries and mortality caused by entanglement, and may also deplete prey resources.

While the steady erosion of habitat quality through human activities is pervasive and complex, the threats posed by fishing activities are more evident, immediate and comparatively easier to manage. Globally, bycatch of cetaceans in fishing nets has been estimated at $>300000$ individuals $\mathrm{yr}^{-1}$ (Burns \& Wandesforde-Smith 2002, Read et al. 2006). While indirect impacts of fishing are more difficult to characterise, fishing can also affect dolphins by depleting their prey and altering the habitat upon which the dolphins and their prey rely. Reports on the Taiwan ocean fisheries sector in general, beyond the Taiwan Strait, indicate that entanglement in fishing nets causes 1000s of deaths of several species of small cetaceans (see Perrin et al. 2005, Chou 2006).

The direct link between fishing activities and dolphin bycatch provides decision-makers with clear management options that will contribute to the recovery of the Critically Endangered ETS Sousa. We conducted a review of fishing practices in Taiwan to evaluate the implications for these dolphins, many of which have scars indicative of net-related injuries.

\section{DIRECT EFFECTS OF FISHING}

\section{Risks from different fishing techniques}

We reviewed humpback dolphin bycatch internationally and found that incidental catches in fishing gear have been documented virtually everywhere 
humpback dolphins have been studied (e.g. Harwood \& Hembree 1987, Parsons \& Jefferson 2000, Baldwin et al. 2004, Jefferson \& Hung 2004, Van Waerebeek et al. 2004, Kiszka et al. 2008, Jaaman et al. 2009). The primary types of gear involved are gill or trammel nets (both set and drifting) and trawls, although several other fishing techniques have also been suggested to cause mortality (Fig. 2).

Gillnets (including trammel nets) pose the highest risk in terms of humpback dolphin entanglement. A standard gillnet consists of a single layer of netting, usually made of monofilament (sometimes multifilament) nylon line. Target fish are caught after they swim through the mesh of the net and become snared by the gill covers when they try to back out of the net. Gillnets also catch many other animals, including larger fish, dolphins and whales.

Trammel nets are made of multiple (usually 3 ) layers of monofilament netting, with the intention of entangling organisms rather than catching them by the gill covers. Two layers of netting on either side of the middle layer are usually of a larger mesh size and looser than the middle layer. The greater 'slack' in trammel nets increases their ability to entangle fish and other animals. However, many simple gillnets used in Taiwan are also relatively loosely hung and act more like an entangling net (i.e. similar to a trammel net). Both gillnets and trammel nets can be secured to the seafloor with anchors or weights and

(a) Gillnet ↔Shore

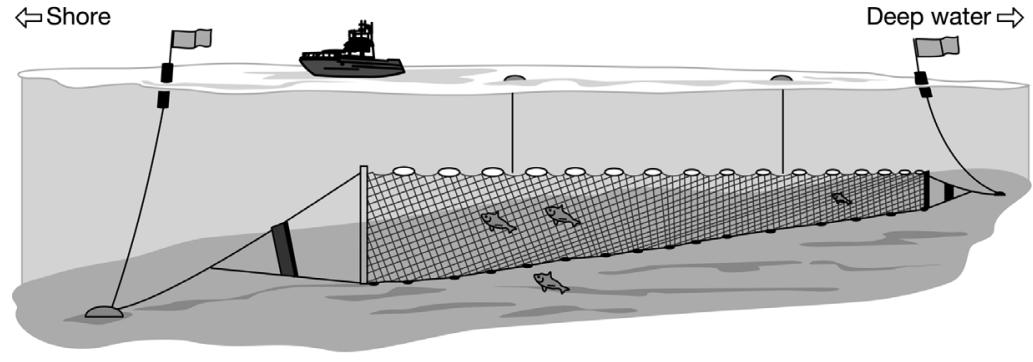

(b) Otter trawl net

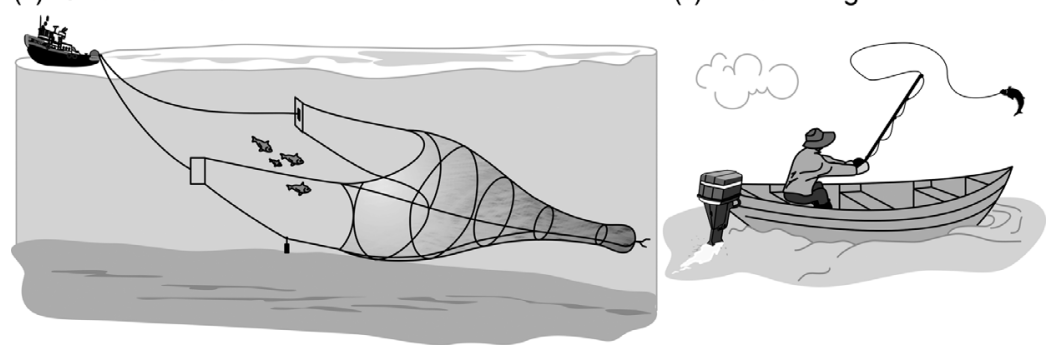

Fig. 2. Fishing gear types and their risk level in terms of dolphin entanglement. (a) High risk: trammel nets (not shown) and gillnets; (b) medium risk: trawling; (c) low risk: hook-and-line/pole fishing; figures redrawn from Nedelec \& Prado (1990) are then often called set gillnets, bottom-set gillnets, or setnets. Alternatively, they can be left drifting near the water surface and are then called drifting gillnets or driftnets.

Gillnets and trammel nets affect virtually every group of marine mammals, with some types of dolphins and porpoises being particularly vulnerable (Jefferson \& Curry 1994, Young \& Iudicello 2007). They are responsible for the majority of marine mammal fishery mortality in the USA (Read et al. 2006) and probably worldwide. Major bycatch issues have been documented for humpback dolphins in antishark gillnets deployed in South Africa and Australia to protect bathers (Bannister 1977, Cockroft 1990, Cockroft \& Krohn 1994, Gribble et al. 1998), and, at least in South Africa, these have endangered local dolphin populations (Cockroft 1990).

Trawl nets are considered a medium risk. Although trawls affect a large number of different species of marine mammals, they generally have a lower level of impact than gillnets (see Fertl \& Leatherwood 1997). However, in certain situations they can be a major problem. For instance, most of the mortality and injuries associated with net entanglement in Hong Kong, where humpback dolphins have been extensively studied, are thought to be related to trawlers (Jefferson 2000, Jefferson et al. 2006). In Hong Kong waters, dolphins follow trawlers to feed on discarded fish bycatch (Jefferson 2000), but, in some other areas, including Taiwan, such trawler associations (and thus entanglement) have not been observed to date. However, there is 1 anecdotal report of an ETS Sousa caught in a trawl net.

Longlines and other hook-and-line methods are considered the lowest risk for ETS Sousa. In general, these fishing techniques only have significant impacts on populations of species that are known to actively remove fish and/or bait from the hooks, such as sperm whales Physeter macrocephalus, killer whales Orcinus orca, pilot whales Globicephala spp. and false killer whales Pseudorca crassidens (Gilman et al. 2006, Garrison 2007, Forney et al. 2011). There is currently no evidence that humpback dolphins do this, and, in any case, longlines are most often used in waters deeper than the most typical depth range in which humpback dolphins are found. 
Finally, there is no evidence that purse seines, which have major impacts on some populations of oceanic dolphins, are a serious problem for humpback dolphin populations. Large-scale purse seines are not known to operate in inshore waters along western Taiwan. Aquaculture activities may be problematic for humpback dolphin populations in some areas, both through entanglement in lines and nets and in terms of habitat loss and pollution. This needs to be investigated further.

Scant information is available on cetacean bycatch in Taiwanese waters, but 1 report based on surveys of fishers estimated that 560 cetaceans are captured annually from the eastern fishing port of Shihti Harbour and 2210 from Chengkung Harbour (Chou 2006), so just for these 2 ports, the total cetacean catch was estimated to be almost 2800 cetaceans $\mathrm{yr}^{-1}$. Estimates for the western coastal region (where ETS Sousa is found) are unavailable, but given the similar approach to fisheries management and conservation by the local fisheries authorities cetacean bycatch along western Taiwan is concerning.

\section{Overlap between Sousa chinensis and fisheries}

There is considerable overlap between ETS Sousa habitat and the use of types of fishing gear known to cause dolphin mortality, including gillnets and trammel nets (Ross et al. 2010, Dungan et al. 2011). Trammel nets are by far the most prevalent kind of entangling net used in the inshore waters along western Taiwan, while single-mesh gillnets are used less frequently.

Fishers using gill and trammel type nets in the waters along western Taiwan number in the 1000s and are found in almost every fishing port along western Taiwan (see Tables 1 \& 2). Most of these fishers operate from small rafts made of polyvinyl chloride (PVC) pipes. However, larger vessels up to at least 'CT3' boats (20 to 50 t) have also been seen setting trammel nets in inshore waters.

Trawl fisheries also pose threats to dolphins. There is at least 1 report of a humpback dolphin that was killed by a trawler fishing along western Taiwan, and trawl nets are known to kill this species elsewhere (e.g. Jefferson 2000, Jefferson et al. 2006). Various types of trawls are used within the habitat of ETS Sousa, including pair trawls, otter trawls, larval fish ('bulah') trawls and beam trawls.

Set traps are also known to capture coastal small cetaceans, including harbour porpoises Phocoena phocoena in the Bay of Fundy (Smith et al. 1983), while stow nets have captured dolphins and finless porpoises in mainland Chinese waters (Zhou \& Wang 1994, Yang et al. 1999, 2000). The only known set trap found in the priority habitat of ETS Sousa (see Ross et al. 2010) was in Hsinchu County. Other species of dolphin have been reported caught in this trap, and therefore such traps also pose a threat to ETS Sousa.

Finally, non-net fisheries are also found throughout the distribution of ETS Sousa and may pose additional threats. Many fishers use hook-and-line methods, which are less harmful to dolphins and other marine life, including fish stocks. However, more effort is needed to encourage proper, onshore disposal of fishing-related trash (used lines, hooks, plastic packaging, etc.). Fishing lines (especially the new, low diameter, low-stretch braided, or fusion lines) left discarded in the water can entangle dolphins and other marine life, resulting in severe injuries and death (e.g. Barco et al. 2010). Lines and trash can also accumulate on structures within aquaculture beds, increasing the risk of injury associated with such facilities.

\section{Data sources}

We analysed 2 sources of information on fishing effort within ETS Sousa habitat: (1) data collected by researchers from the FormosaCetus Research and Conservation Group and (2) data available from the Taiwan Fisheries Statistical Yearbook (Fisheries Agency 2010).

First, fisheries data from the FormosaCetus Research and Conservation Group, collected from 2007 to 2010 as part of its cetacean survey protocol, were collated and analysed. In addition to recording dolphin sightings and other standard survey information (e.g. weather conditions), all fishing vessels and gear within approximately $1 \mathrm{~km}$ of the survey boat were recorded, including floats and markers attached to set fishing nets. We assumed that fishing floats with flags (high flyers) marked trammel nets and that a single trammel net would be represented by 2 high flyers.

The surveyed area was partitioned into 3 blocks (comprising waters of 2 counties each; Fig. 1). An estimated 0.013 trammel nets were seen per kilometre of survey effort in the northern block (waters of Miaoli \& Taichung counties), and 0.056 in the central block (waters of Changhua \& Yunlin counties) (Table 1). No data on fishing activity were available for the southern block (Chiayi \& Tainan counties). These levels of 
Table 1. Data from boat surveys for Sousa chinensis (Sousa) and fishing gear off western Taiwan, carried out by FormosaCetus Research and Conservation Group from 2007 to 2010. Data on high flyers were not collected systematically during the surveys in Chiayi and Tainan counties (NA: not available). Survey effort refers to the length of the survey transects. The number of sightings and number of eastern Taiwan Strait (ETS) Sousa include multiple resightings of individuals during the 4 yr period

\begin{tabular}{|lcccccccc|}
\hline Counties & $\begin{array}{c}\text { Survey } \\
\text { effort }(\mathrm{km})\end{array}$ & $\begin{array}{c}\text { No. of } \\
\text { sightings }\end{array}$ & $\begin{array}{c}\text { Sightings } \\
\left(\mathrm{km}^{-1}\right)\end{array}$ & $\begin{array}{c}\text { Total no. of } \\
\text { ETS Sousa }\end{array}$ & $\begin{array}{c}\text { ETS Sousa } \\
\mathrm{km}^{-1}\end{array}$ & $\begin{array}{c}\text { Total no. of } \\
\text { high flyers }\end{array}$ & $\begin{array}{c}\text { High flyers } \\
\mathrm{km}^{-1}\end{array}$ & $\begin{array}{c}\text { Trammel } \\
\mathrm{nets} \mathrm{km}^{-1}\end{array}$ \\
\hline Miaoli \& Taichung & 1875 & 42 & 0.022 & 225 & 0.120 & 50 & 0.027 & 0.013 \\
Changhua \& Yunlin & 4136 & 85 & 0.021 & 693 & 0.168 & 463 & 0.112 & 0.056 \\
Chiayi \& Tainan & 70 & 3 & 0.043 & 9 & 0.129 & NA & NA & NA \\
All & 6081 & 130 & 0.021 & 927 & 0.152 & 513 & 0.084 & 0.042 \\
\hline
\end{tabular}

fishing effort were similar to, or greater than, those observed in other parts of the world where bycatch has caused population declines in cetacean populations (e.g. Hector's dolphin Cephalorhynchus hectori; Slooten et al. 2000, Slooten \& Dawson 2010, Slooten \& Davies 2012; harbour porpoise Phocoena phocoena in California, USA; Forney et al. 2001). Insufficient data from Taiwan were available on trawlers and other fisheries for similar analyses to be meaningful.

Secondly, data gathered by Taiwan's Fisheries Agency (2010) showed that a total of 6318 motorised fishing vessels, including sampans, rafts and other motorised fishing craft, operated from ports in the 6 coastal counties included in the dolphins' habitat in 2009. All of these vessels are capable of deploying gill and/or trammel nets that can kill or injure dolphins (Table 2, Fig. 3), and $45 \%$ are described as engaging in 'coastal' fishing within 12 nautical miles (n miles) from shore. Within the $200 \mathrm{~km}$ from northern Miaoli to southern Tainan (Sousa habitat), the number of fishing craft capable of using gillnets averaged $32 \mathrm{~km}^{-1}$.

It is clear from the data on the number of fishing vessels and number of gillnets and trammel nets per kilometre that there is a very high risk of fisheries mortality for ETS Sousa, especially given the very small size of the population, its restricted distribution and its limited ability to withstand human impacts (see 'Consequences of fisheries mortality for conservation'). More detailed and accurate fishing effort data, in particular regarding fishing effort with gillnets, trammel nets and trawling, in Sousa habitat are urgently needed, to inform and guide conservation and management efforts
Table 2. Total number of motorised fishing craft capable of gillnet/trammel net fishing based in the major harbours of the 6 counties adjacent to Sousa chinensis habitat (Fisheries Agency 2010)

\begin{tabular}{|lccccc|}
\hline County & Trawlers & Gillnetters & Rafts & Sampans & Total \\
\hline Miaoli & 1 & 19 & 592 & 88 & 700 \\
Taichung & 40 & 125 & 669 & 103 & 937 \\
Changhua & 1 & 123 & 313 & 139 & 576 \\
Yunlin & 0 & 22 & 1557 & 47 & 1626 \\
Chiayi & 1 & 53 & 1485 & 117 & 1656 \\
Tainan & 4 & 114 & 555 & 150 & 823 \\
Totals & 47 & 456 & 5171 & 644 & 6318 \\
\hline
\end{tabular}

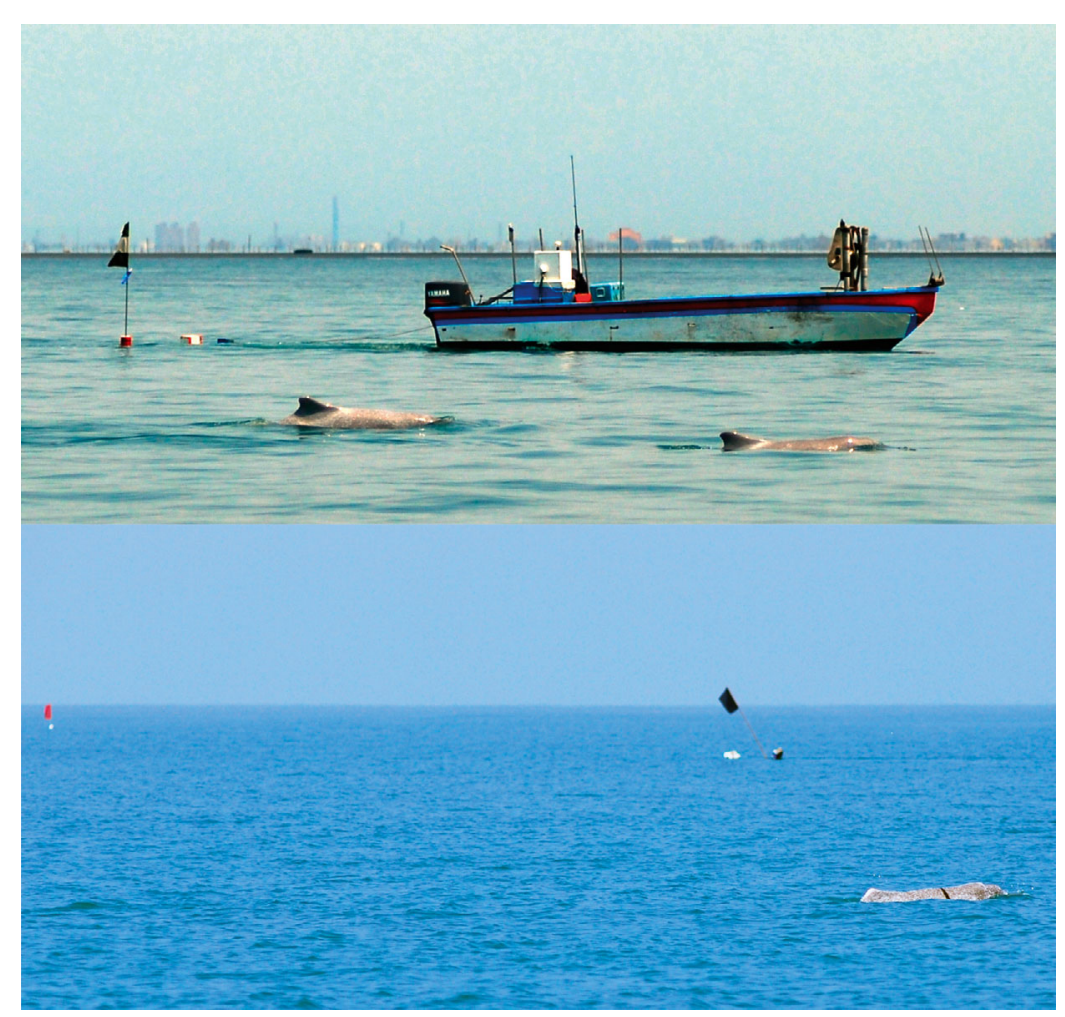

Fig. 3. Trammel nets and eastern Taiwan Strait Sousa, clearly showing the high flyer flags used on floats attached to trammel nets. Note the piece of fishing gear (rope) attached to the dolphin in the lower panel. Photographs by J. Y. Wang, FormosaCetus Research and Conservation Group 
in Taiwan. Additional data would help to refine solutions to the problem. However, the currently available data clearly indicate that bycatch of ETS Sousa is a serious threat to this small population (see 'Consequences of fisheries mortality for conservation'), and protection of this species needs to be improved immediately to avoid its extinction.

\section{Direct evidence of entanglement}

Fisheries have been known to lead to serious injury or mortality in many marine mammal species worldwide (Angliss \& DeMaster 1998, Read \& Murray 2000, Andersen et al. 2008, Wells et al. 2008, Thiele 2010). To characterise the risk of entanglement to the ETS Sousa population, we used data from a photo-identification project that has been ongoing since 2002. Surveys were carried out in the coastal waters of western Taiwan, mainly in the summer months (April to August) with 3 winter surveys conducted over 4 mo in 2008/2009 (Wang et al. 2007a, 2012, Wang \& Yang 2011). We examined photographs from this study for evidence of fisheries-related injuries. Only scars and disfigurements that are most likely due to interactions with fisheries, such as those from fishing lines or nets, were included in this examination (Fig. 4). Injuries sustained from blunt force trauma, vessel propellers, or uncertain causes were not included as they may have been due to non-fishing vessels. Where photographic evidence made it possible, we examined the entire body of individual dolphins over a number of years. Images were classified in a manner similar to that used by Thiele (2010), although our categories were developed to focus more on fisheries-related injuries: (1) no markings indicative of human interaction, (2) markings of clear anthropogenic origin and (3) distinctive markings from line and net entanglements. We examined photographs for markings considered diagnostic of net injuries as described by Angliss \& DeMaster (1998).

Gillnet injuries are often associated with long, linear lacerations, but can also be identified by marks on the leading edges of flukes, pectoral fins and/or dorsal fins; gillnet marks on the body (such as those found on the beak of a freshly dead ETS Sousa that stranded on 25 September 2009); and deep grooves in the caudal peduncle and the loss of whole or partial appendages (e.g. tail, dorsal fin, pectoral fin; Fig. 4). Similar injuries, such as cleanly amputated appendages, can also be attributed to interactions with other types of gear, such as fishing line (Kuiken 1996)

Markings consistent with constrictive line wraps around the body were categorised as fisheriesrelated injuries (Wells et al. 2008). One individual was photographed in 2008 with constrictive fishing gear wrapped around its torso, but has since shed the gear and appears to be in good physical condi-
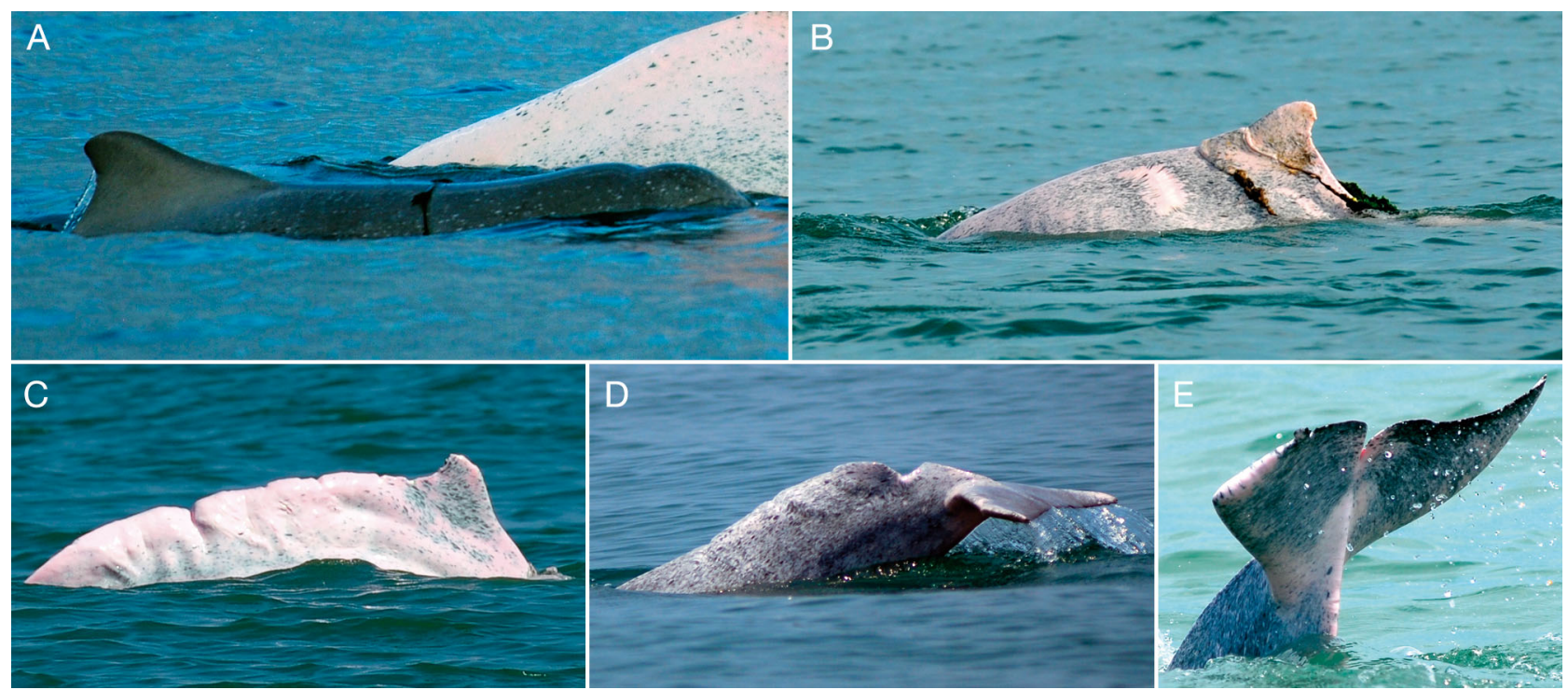

Fig. 4. Sousa chinensis. (A,B) Eastern Taiwan Strait Sousa entangled in fishing gear or (C,D,E) bearing injuries caused by fishing gear entanglement. These include adults (B,C), an individual between 2 and $4 \mathrm{yr}$ old (A) and individuals of intermediate age $(D, E)$. One individual $(E)$ has lost half of the left lobe of the tail fluke. In all cases, the fishing gear appears to be monofilament line, likely from trammel nets or gillnets. Photographs by J. Y. Wang, FormosaCetus Research and Conservation Group 
tion (see Fig. 3 in Ross et al. 2010). Our results indicate that of 93 individuals identified since 2002, 1 died as a result of net entanglement and 49 (52.7\%) exhibited evidence of human-caused injury. We carefully examined these injuries and concluded that over half $(59.2 \%)$ originated from fisheries interactions, with 29 of the 93 (31.2\%) identifiable individuals having fisheries-related wounds. Photographs of the entire body were not available for all individuals, so fisheries-related injuries are likely under-represented in our analysis. Furthermore, identification of all individuals in every year was not feasible, and any injuries sustained in a year without available photographs would have gone undetected.

The strongly human-modified nature of the west coast of Taiwan (e.g. concrete seawalls and breakwaters) reduces the likelihood of a dead dolphin stranding. Therefore, non-lethal fisheries injuries are more likely to be detected, while the proportion of fisheries interactions that results in mortality is likely to be underestimated. In addition, external morphology does not allow us to characterise the proportion of individuals that may have ingested fishing gear, which can also lead to death (Wells et al. 2008). Therefore, our analysis provides a conservative risk assessment with respect to fisheries-related injuries for ETS Sousa. Given the high percentage of identified dolphins with fisheries-related injuries, it is clear that the risk of entanglement in fishing gear is high for these small coastal dolphins. The stranded individual from 25 September 2009 (TW-03) was the only fresh specimen of 3 confirmed Sousa stranding events between August 2000 and September 2009 along western Taiwan that could be examined for fishery-related injuries, and this individual exhibited clear signs of gillnet entanglement. In 2012, 2 more dolphins were observed with constrictive fishing gear wrapped around their torsos, and 2 lines that were slowly slicing into the dorsal fin at 2 different locations (both had been seen without fishing gear the previous year) (Fig. 4).

\section{INDIRECT EFFECTS OF FISHING}

Aside from direct contact between dolphins and fishing gear, fishing activity in dolphin habitat may have indirect effects on the health of individuals and populations. These effects include: depletion of prey resources, pollution, noise disturbance, altered behavioural responses to prey aggregation in fishing gear and potential changes to social structure arising from the deaths of individuals caused by fisheries activity.

\section{Depletion of prey resources}

In recent years, individual ETS Sousa have been observed in poor body condition (emaciated; Fig. 5), indicating that nutritional stress and/or subsequent disease may be a problem. In some other marine mammal species, poor body condition has been linked to reduced prey availability or quality (Lockyer 1986, Read 1990, Haug et al. 2002), and, in some cases, this has been linked to fishing activity (e.g. Steller sea lions Eumetopias jubatus; Trites \& Donnelly 2003, Hennen 2006).

Fisheries can deplete prey resources directly by removing prey species from the habitat. For example, in the eastern Ionian Sea, the rapid decline of short-beaked common dolphins Delphinus delphis has been caused in major part by resource overlap between dolphins and purse-seine fisheries (Bearzi et al. 2006, 2008). Fisheries on the Taiwanese west coast are unlikely to target dolphin prey species directly, because these species (e.g. Johnius spp. [Barros et al. 2004] and clupeids) are too small, low in abundance and of little commercial value. However, most non-target fish caught by gillnets and trawlers are retained and sold in markets or used for producing fish-meal for aquaculture feed. These prey resources may also be shared with other predatory fish. Over-exploitation of smaller species can thus put stress on multiple predator populations and reduce the catch rates of fisheries that target larger, more commercially valuable species. For example, in the eastern Ionian Sea, over-fishing of small species, including sardines and anchovies, by purse-seiners has likely contributed to the decline in encounter and catch-rates of tuna and swordfish (Bearzi et al. 2006).

Better enforcement of the existing $3 \mathrm{n}$ mile trawling ban in the inshore waters off western Taiwan would help to reduce fishing impacts on ETS Sousa and the fish populations with which they share their habitat. However, this would not be sufficient by itself to reduce fisheries impacts on the dolphins to sustainable levels. Over-fishing has caused the alteration or collapse of coastal ecosystems in several parts of the world (Jackson et al. 2001, Pauly et al. 2002, Tillin et al. 2006, Shephard et al. 2010). Strictly managing fisheries so that they are sustainable for all species caught can help restore ecosystems to pre-exploitation levels of productivity (Pitcher 2001) and, in Tai- 
wan's case, would benefit both dolphins and fisheries in the long term.

\section{Pollution in the fisheries sector}

Pollution caused by fisheries may also indirectly affect dolphin populations by reducing habitat quality and creating health risks. Discarded or lost fishing gear, which persists for a long time in the marine environment and can travel over long distances, poses a significant hazard that can injure or kill marine mammals within and outside of active fishing areas (Kaiser et al. 1996). Pollutants released into the marine environment during fishing activities (e.g. oil discharge, trash, boat exhaust, discarded near-empty paint cans) also contribute to the contaminant load within the food-web. Anti-fouling paints are also a concern, given the high level of butyltins found in the Indo-Pacific humpback dolphin population of the
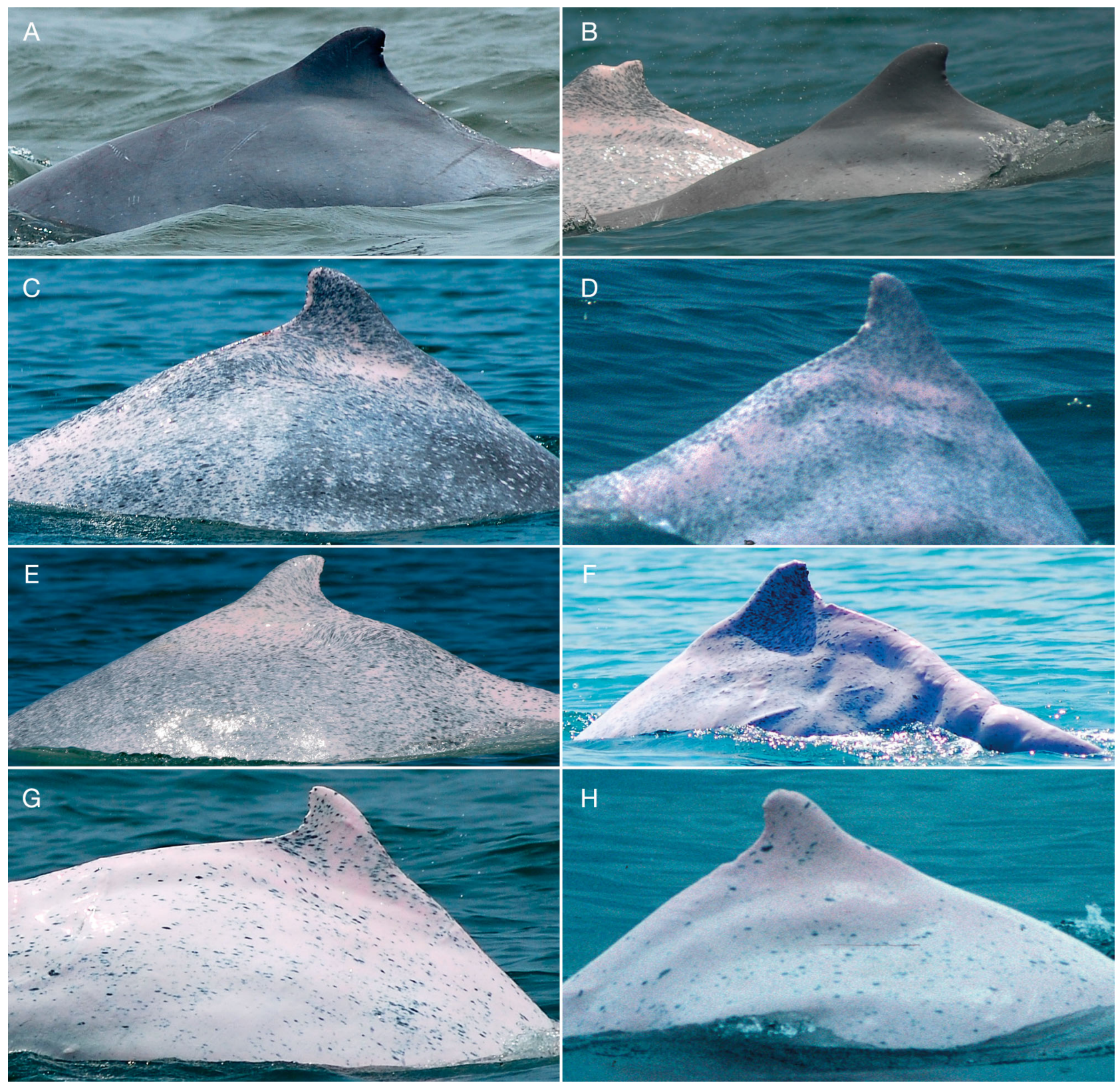

Fig. 5. Sousa chinensis. Eastern Taiwan Strait Sousa in $(A, C, E, G)$ good and $(B, D, F, H)$ poor body condition for different pigmentation (and likely relative age) classes. Photographs by J. Y. Wang, FormosaCetus Research and Conservation Group $(\mathrm{A}, \mathrm{B}, \mathrm{C}, \mathrm{F}, \mathrm{G}, \mathrm{H})$ and S. C. Yang, FormosaCetus Research and Conservation Group (D,E) 
Pearl River Estuary (PRE) (Lawler \& Aldrich 1987, Takahashi et al. 2000).

Bottom-trawling and other disturbances of the seafloor (e.g. by bottom-set nets) can re-suspend the upper layers of sediment, re-mobilising previously settled contaminants in the process (Kaiser et al. 2001). Some of these contaminants can accumulate in the tissues of fish and other marine species, reaching very high concentrations in top predators, such as cetaceans (Ross et al. 2000), and in some humans (Corsolini et al. 2005). In the case of persistent organic pollutants, including PCBs, such bioaccumulation in marine mammals can alter normal growth and development, cause cancer, reduce immune function and affect reproductive health (DeLong et al. 1973, Helle et al. 1976, Reijnders 1986, Mortensen et al. 1992, Ross et al. 1996, Ylitalo et al. 2005). There is very little information on contaminant levels in ETS Sousa, but high levels of persistent organic pollutants in PRE Sousa are considered as risks to their health (Minh et al. 1999, Parsons 2004, Leung et al. 2005, Jefferson et al. 2006). High rates of neonatal mortality in the PRE Sousa may be caused by exposure of breeding females to environmental contaminants (Jefferson et al. 2012).

\section{Behavioural responses to prey aggregation}

Some fishing activities have the potential to attract dolphins due to the aggregation of prey in fishing nets (e.g. gillnets, trammel nets and trawl nets). This has been documented, for example, for Hector's dolphins (Rayment \& Webster 2009) and PRE Sousa, which are known to follow trawlers in unusually large groups (Jefferson 2000). Mothers with calves may be particularly drawn to fishing operations because they have higher energetic demands, putting them and especially their calves at greater risk of entanglement (Fertl \& Leatherwood 1997). A disproportionate preference by mothers for feeding in association with pair trawlers is suspected for PRE Sousa (Jefferson 2000, Hung 2008). Females with calves tend to prefer areas of high prey density (e.g. Weir et al. 2008), which can result in greater overlap of habitat use by fisheries and mother-calf groups than other individuals. Over the long term, behavioural habituation to feeding in association with fishing activities can result in permanent social structure changes because calves learn foraging behaviours from their mothers (e.g. Shane et al. 1986). For example, in Moreton Bay, Australia, Chilvers \& Corkeron (2001) described 2 sympatric bottlenose dolphin social units; one had a preference for feeding in association with trawlers, making it more exposed to harmful fisheries interaction than the other. The authors suggested that the 2 social units might have formed in response to trawling activity.

\section{General behavioural consequences arising from individual deaths}

The death of a single individual may have a disproportionate impact on a population because of the differing social roles among individuals. Cetaceans, and especially delphinids, often have a highly complex social structure (e.g. Connor et al. 1998). Specific individuals or classes of individuals (e.g. juvenile female killer whales; Williams \& Lusseau 2006) may have disproportionately important roles in foraging, rearing of offspring and the transmission of functionally important behaviours within and between generations (Whitehead et al. 2004). For example, foraging efficiency of bottlenose dolphins in Doubtful Sound, New Zealand, depends on the knowledge possessed by a few key individuals (Lusseau \& Conradt 2009). The removal of such individuals from their social network would reduce the speed of information transfer through the population (Lusseau 2003), potentially diminishing the population's ability to rapidly adapt to changing environments (Rendell \& Whitehead 2001).

Specific individuals can also act as repositories of socially learned, functionally important survival or reproduction-related information. Among mammals with complex social structures, including cetaceans, this role has been particularly emphasised for matriarchs (Boran \& Heimlich 1999, Yurk et al. 2002). Killer whale calves without adequate training by experienced mothers were less proficient when foraging and had lower catch-rates than calves that received more maternal training (Guinet \& Bouvier 1995).

Matrilineal social structure has not been conclusively demonstrated for humpback dolphins, but post-reproductive female longevity (a hallmark of matrilineal societies; McAuliffe \& Whitehead 2005) is suspected in both the PRE (Jefferson et al. 2012) and ETS populations (Dungan 2011). Breeding females appear to have important social network positions in ETS Sousa. As such, the loss of 1 breeding female from the ETS population to fisheries could be important, not only from a purely demographic perspective, but could also reduce the survival or reproductive success of other individuals. For example, in another delphinid species post-reproductive females have 
been shown to substantially improve the survival of their offspring, even many years after birth (Foster et al. 2012).

\section{CONSEQUENCES OF FISHERIES MORTALITY FOR CONSERVATION}

Like other small cetaceans, Sousa is a long-lived animal with a slow reproductive rate. Maximum population growth rates for dolphins are on the order of 2 to $4 \% \mathrm{yr}^{-1}$ (e.g. Perrin \& Reilly 1984). This means that even a low level of fisheries mortality poses a serious risk to the small ETS Sousa population. We used a standard, internationally recognised assessment method (potential biological removal or PBR; Wade 1998, Taylor et al. 2000) to evaluate the sustainability of human impacts on the ETS Sousa population. PBR is an estimate of the maximum number of individuals, not including natural mortality, that may be removed while allowing the population to recover toward or maintain its optimum sustainable population size. The calculation of PBR explicitly takes into account the population's status and uncertainty in the available data.

Accurate knowledge of population structure is crucial for the PBR method, and most other methods of assessing sustainable levels of human impact (e.g. Wade 1998, Wang 2009). For example, under the US Marine Mammal Protection Act, it is recognised that the first step in managing marine mammal populations is to correctly identify the appropriate unit to conserve, or 'stock' (Taylor 1997) - either a demographically isolated population or a portion of the species' range where impacts (e.g. bycatch) are concentrated (NMFS 2005). Demographic isolation results when a group's population dynamics are more strongly determined by births and deaths within the group than by immigration or emigration. In such a case, immigration would not be sufficient to prevent a population from potentially declining in the face of anthropogenic impacts, and the group of animals should be considered a separate stock for management purposes. Many types of information can be used to identify stocks of a species: distribution gaps; movement patterns of individual animals; morphological differences including colouration, size, or shape; differences in life history or genetic markers; population trends; patterns of contaminant, parasite and natural isotope loads; and habitat differences (see Wang 2009).

Impacts of fisheries mortality and other human activities must be addressed with respect to the size of the population in the coastal waters of Taiwan. A preliminary study comparing mtDNA of 1 ETS Sousa with a small number of individuals from other populations failed to find evidence for genetic differences between ETS Sousa and other Sousa populations (see Chou 2006). Of course, a lack of evidence for genetic distinctiveness does not mean evidence for 1 panmictic population. Reasons for failing to detect population differences include inadequate sample size and therefore statistical power, inappropriate choice of marker(s) and insufficient time since divergence to allow differences to develop (see Taylor \& Dizon 1999, Reeves et al. 2004, Wang 2009, Taylor et al. 2010). However, there is ample other evidence that ETS Sousa represents a demographically isolated population, including its limited and discrete geographic range, lack of movements of individuals to other areas inhabited by Sousa, a marked habitat discontinuity between shallow coastal water areas of western Taiwan and coastal mainland China and phenotypic differences. Colouration has been used as an important phenotypic character in cetacean taxonomy (Perrin 2009). The pigmentation of ETS Sousa is markedly different from Sousa inhabiting the shallow coastal and estuarine-influenced waters of mainland China (Wang et al. 2008), indicating genetic and demographic isolation.

Photo-identification studies have not documented any movement of individuals among 3 locations, despite substantial catalogues ( 35 ETS, 400 PRE and $\sim 10$ JRE [Jiulong River Estuary] individuals; Wang et al. 2008) that were systematically compared to identify matches. The ETS and PRE catalogues have since grown to $>90$ and 700 individuals, respectively, yet still there are no individuals that are common to both locations. The species has not been reported in waters deeper than about $30 \mathrm{~m}$ (Jefferson \& Karczmarski 2001), while the depth of the main body of the Taiwan Strait is mostly >50 m (up to $70 \mathrm{~m}$ ) and appears to be an effective oceanographic barrier against movement of the species across the strait. There is also direct evidence for year-round residency of ETS Sousa in the waters off western Taiwan, with no indication of seasonal changes in distribution (Wang \& Yang 2011). Thus, multiple lines of evidence indicate that ETS Sousa represents a distinct and demographically isolated population, and it is recognised as a distinct, critically endangered, subpopulation in the IUCN Red List (Reeves et al. 2008).

Having determined that it is appropriate to calculate a PBR for the ETS Sousa population, we used the following standard formula (Wade 1998): 
$\mathrm{PBR}=N_{\min } \times 1 / 2 R_{\max } \times F_{\mathrm{r}}$ where $N_{\min }$ is the minimum population size (the 20th percentile of a statistically based population estimate or an actual count of distinct individuals), $R_{\max }$ is the maximum net population growth rate, and $F_{\mathrm{r}}$ is a recovery factor that allocates part of the population's growth to recovery and/or allows for uncertainty in population status. The assessment method provides default values of $R_{\max }$ based on taxonomic grouping (e.g. cetaceans, pinnipeds) when estimates are not available. Further, guidelines have been established for setting recovery factors based on population status, trends and designation as threatened or endangered (Taylor et al. 2000).

Two population estimates are available for ETS Sousa. A 2002 to 2004 line-transect survey resulted in a population estimate of 99 individuals $(\mathrm{CV}=0.516$; Wang et al. 2007a) and an $N_{\text {min }}$ of 66 individuals. A recent mark-recapture study resulted in an estimate of 74 individuals ( $\mathrm{CV}=0.04$; Wang et al. 2012), with an $N_{\min }$ of 71 . No estimate of the maximum annual population growth rate is available for ETS Sousa. Therefore, we used the cetacean default value of 0.04. Given the Critically Endangered status of this population, the recovery factor $F_{\mathrm{r}}$ is 0.1 (Wade 1998, Slooten \& Dawson 2008). Using the 2 abundance estimates, this resulted in a PBR of 0.13 or 0.14 ind. $\mathrm{yr}^{-1}$, or no more than 1 human-caused dolphin death every 7 to 7.6 yr. If we assumed the population status was unknown, rather than Critically Endangered, the recovery factor of 0.5 would result in a PBR of 0.66 or 0.71 ind. $\mathrm{yr}^{-1}$ (i.e. still <1 dolphin $\mathrm{yr}^{-1}$ ). Thus, our conclusion that a human-caused mortality of even 1 dolphin $\mathrm{yr}^{-1}$ would pose a serious threat to this population was not sensitive to assumptions about the population's threat status, the recovery factor (i.e. 0.1 or 0.5$)$, or the population estimate used.

Importantly, the PBR model properly includes all non-natural mortality caused by fishing, pollution, ship strikes, habitat destruction and other human activities. Given the overlap between ETS Sousa and extremely high levels of fishing effort with gear and methods known to catch and kill dolphins wherever they are used worldwide (Perrin et al. 1994, Read et al. 2006) and the high levels of other risk factors in the Taiwan Strait, the total level of human-caused mortality almost certainly exceeds the calculated PBR. Given that a single dolphin death per year exceeds the PBR by a factor of up to 7, it is essential that all bycatch be eliminated. This is a particularly serious concern because 1 individual was documented to have been killed in fishing gear in 2009 (TW-03), despite the lack of a systematic bycatch monitoring program.

\section{EFFECTIVE SOLUTIONS}

The information reported above makes it clear that there is substantial overlap in range between ETS Sousa and the use of several kinds of fishing gear known to cause mortality in Sousa and other dolphin species. It is clear that bycatch in coastal fisheries, even in the absence of any other human-caused mortality, is a major threat to this population. Applying management, regulation and enforcement strategies to reduce the impact of fisheries on ETS Sousa also represents a constructive and practical means of recovering the population, since many of the other threats are much more difficult to study, quantify and/or manage.

To reduce the extremely high extinction risk for ETS Sousa it is important to eliminate fisheries mortality as soon as possible. Based on our extensive review of the international experience, the following measures can be considered effective for eliminating bycatch of ETS Sousa in fishing gear:

(1) Implement effective fishing regulations to prevent the use of trammel nets, gillnets and trawling throughout ETS Sousa habitat.

(2) Strictly enforce existing regulations that prohibit the use of trawlers within $3 \mathrm{n}$ miles from shore, as well as all new regulations implemented in (1).

We also evaluated several other mitigation measures that have been attempted elsewhere, but unanimously concluded that the following measures would not be effective for ETS Sousa:

(i) Acoustic devices (pingers). These may alert cetaceans to the presence of a fishing net. The devices can reduce bycatch for some species, but they do not eliminate bycatch as will be required for ETS Sousa (e.g. Cox et al. 2001, 2003, 2007, Dawson et al. 1998, 2013). Further, pingers can displace or exclude small cetaceans from important portions of their habitat (e.g. important feeding areas) and therefore could cause further harm to ETS Sousa. If dolphins habituate to their presence, pingers may act to attract dolphins to nets (especially if the dolphins are removing fish from nets or feeding on scavengers around the nets), increasing rather than decreasing the risk of entanglement (e.g. Cox et al. 2001, 2004, 2007, Dawson et al. 1998, 2013). These concerns are particularly serious where fishing effort is substantial, as in the habitat of ETS Sousa.

(ii) Gillnet modification (e.g. metal oxide with barium sulphate). This has been tested with several species and has not been shown to eliminate bycatch in any cetacean population (e.g. Trippel et al. 2003, Larsen et al. 2007). 
(iii) Seasonal area closures. There is insufficient knowledge about fisheries dynamics and patterns of seasonal Sousa bycatch and habitat use to ensure the survival of this population by applying this type of measure. The lack of obvious seasonal patterns in ETS Sousa distribution or abundance (e.g. Wang \& Yang 2011) indicates that such closures would not be effective. Experience with other endangered dolphins shows that effective conservation and population recovery requires year-round protection within the entire area occupied by the population of concern (e.g. Rojas-Bracho et al. 2006, Slooten \& Dawson 2010, Gerrodette \& Rojas-Bracho 2011, Gormley et al. 2012).

Preventing the use of trammel nets, gillnets and trawling throughout their habitat would substantially reduce human impacts on ETS Sousa. This is likely to be the single most effective conservation measure that could be implemented for ETS Sousa in the short term. It is certainly important to resolve other impacts, including pollution and habitat degradation, but most of these will require intensive efforts over a long period. By contrast, bycatch of dolphins in fisheries can readily be avoided by using more selective fishing methods (e.g. selective fish traps or hook and line fisheries; see Werner et al. 2006 for a review). Impacts from fishing could be eliminated very quickly, as there are no technical or other practical obstacles to doing so. Other fishing methods are available, and using the most selective, sustainable fishing methods available will benefit not only ETS Sousa but also fish stocks, seabirds and other species, as well as the fishing industry that depends on these species for its long-term viability.

\section{Need for specific targets and timelines}

Given that fisheries entanglement as low as 1 dolphin $\mathrm{yr}^{-1}$ would pose a serious risk to ETS Sousa, timely action is critical. Regulations to prevent the use of trammel nets, gillnets and trawling need to be implemented immediately, effectively and throughout the full range of ETS Sousa habitat in order to reduce the extremely high risk of extinction.

In this context, the Taiwan Fisheries Agency has an opportunity to lead the recovery of ETS Sousa by immediately developing specific targets and dates for eliminating fisheries impacts on ETS Sousa.

\section{COSTS AND BENEFITS OF CHANGING FISHING GEARS}

There will be a short-term cost associated with changing to more selective, sustainable fishing methods. However, we emphasise that long-term solutions that benefit dolphins will also benefit fishers by making nearshore fisheries more sustainable. Longterm fish catches are likely to increase following a shift to using more selective and sustainable fishing methods. More high-valued fish species are also likely to increase and thus bring greater income to the fishers for the same amount of fishing effort.

Although the population size of ETS Sousa is very small, several factors indicate that recovery is likely if fishery mortality is eliminated. Most evidence has shown that marine mammals can recover from small population sizes, as shown in Table 3. Although some individuals have shown signs of poor body condition, most photographically identified ETS Sousa still appear in good condition, and calves are born almost every year (Wang \& Yang 2011, Wang et al. 2012).

Those species of marine mammals that have failed to recover after being reduced by hunting to low levels, such as North Atlantic right whales Eubalena glacialis, southern sea otters Enhydra lutris, and western gray whales Eschrichtius robustus, continued to experience human-caused mortality from entanglement, ship strikes, or other causes at a sufficiently high level to prevent recovery. The same is true for species that have suffered unsustainable

Table 3. Examples of marine mammal population recovery from very small population sizes

\begin{tabular}{|lccc|}
\hline Species & $\begin{array}{c}\text { Estimate of minimum } \\
\text { population size } \\
\text { (approx. year) }\end{array}$ & $\begin{array}{c}\text { Most recent } \\
\text { population size } \\
\text { estimate (year) }\end{array}$ & Source \\
\hline $\begin{array}{l}\text { Northern elephant seal Mirounga angustirostris } \\
\text { Southern sea otter Enhydra lutris }\end{array}$ & $\begin{array}{c}20-100(1890) \\
50(1914)\end{array}$ & $>175000(1991)$ & $\begin{array}{c}\text { Stewart et al. (1994) } \\
\text { Bryant (1915), US Fish \& } \\
\text { Wildlife Service (2003) }\end{array}$ \\
$\begin{array}{l}\text { Guadalupe fur seal Arctocephalus townsendi } \\
\text { Southern right whale Eubalaena australis }\end{array}$ & $<60(1926)$ & $>6400(1993)$ & $\begin{array}{c}\text { Gallo-Reynoso (1994) } \\
\text { Jackson et al. (2008) }\end{array}$ \\
\hline
\end{tabular}


bycatch through long periods of time in local fisheries, such as the baiji Lipotes vexillifer and vaquita Phocoena sinus. There are no known cases of cetacean extinction resulting simply from small population size if risk factors are eliminated.

Experience with other small cetaceans shows that protected areas are effective if they are sufficiently large and effectively manage the main threats (e.g. Rojas-Bracho et al. 2006, Slooten \& Dawson 2010, Gerrodette \& Rojas-Bracho 2011, Gormley et al. 2012). In the case of ETS Sousa, this will require effective protection from bycatch throughout the entire range of this population.

Acknowledgements. This manuscript is the result of an applied workshop held under the auspices of the Eastern Taiwan Strait Sousa Technical Advisory Working Group (ETSSTAWG), an international group of scientists dedicated to providing science-based advice in support of protecting one of the world's most endangered cetaceans. The authors acknowledge with thanks the generous support of the Matsu's Fish Conservation Union, Wild at Heart Legal Defense Association, Winkler Partners, Biodiversity Research Centre, Academia Sinica, NGO Affairs Committee, Taiwan Ministry of Foreign Affairs, Coast Guard Administration, Marine National Park Authority, Taijiang National Park, Kenting National Park, Urban and Rural Development Branch, Construction and Planning Agency, Ministry of the Interior, Executive Yuan, and the Marine Bureau of Kaohsiung City Government. Unpublished data examined and analysed by the workshop participants were provided by the FormosaCetus Research and Conservation Group. We thank J. Barlow, R. Brownell Jr., J. Carretta and W. Perrin for their helpful reviews of this manuscript.

\section{LITERATURE CITED}

Andersen MS, Forney KA, Cole TVN, Eagle T and others (2008) Differentiating serious and non-serious injury of marine mammals: report of the serious injury technical workshop. NOAA Tech Memo NMFS-OPR-39, US Department of Commerce, Washington, DC

Angliss RP, DeMaster DP (1998) Differentiating serious and non-serious injury of marine mammals taken incidental to commercial fishing operations: report of the serious injury workshop. NOAA Tech Memo NMFS-OPR-13, US Department of Commerce, Washington, DC

Baldwin RM, Collins K, van Waerebeek K, Minton G (2004) The Indo-Pacific humpback dolphin of the Arabian region: a status review. Aquat Mamm 30:111-124

Bannister JL (1977) Incidental catches of small cetaceans off Australia. Rep Int Whal Comm 27:506-559

> Barco SG, D'Eri LR, Woodward BL, Winn JP, Rotstein DS (2010) Spectra ${ }^{\circledR}$ fishing twine entanglement of a bottlenose dolphin: a case study and experimental modeling. Mar Pollut Bull 60:1477-1481

Barros NB, Jefferson TA, Parsons ECM (2004) Feeding habits of Indo-Pacific humpback dolphins (Sousa chinensis) stranded in Hong Kong. Aquat Mamm 30:179-188

Bearzi G, Politi E, Agazzi S, Azzellino A (2006) Prey deple- tion caused by overfishing and the decline of marine megafauna in eastern Ionian Sea coastal waters (central Mediterranean). Biol Conserv 127:373-382

Bearzi G, Agazzi S, Gonzalvo J, Costa M and others (2008) Overfishing and disappearance of short-beaked common dolphins from western Greece. Endang Species Res 5: $1-12$

Boran JR, Heimlich SL (1999) Social learning in cetaceans: hunting, hearing and hierarchies. Symp Zool Soc Lond 73:282-307

Bryant HC (1915) Sea otters near Point Sur. Calif Dep Fish Game Bull 1:134-135

Burns WCG, Wandesforde-Smith G (2002) The International Whaling Commission and the future of cetaceans in a changing world. Rev Eur Community Int Environ Law 11:199-210

> Chilvers BL, Corkeron PJ (2001) Trawling and bottlenose dolphins' social structure. Proc Biol Sci 268:1901-1905

Chou LS (2006) Cetacean bycatch in coastal waters of Taiwan and ecology of Chinese white dolphins Sousa chinensis. Report to Fisheries Agency, Council of Agriculture (Taiwan), Taipei

Cockroft VG (1990) Dolphin catches in the Natal shark nets, 1980-1988. S Afr J Wildl Res 20:44-51

Cockroft VG, Krohn R (1994) Passive gear fisheries of the southwestern Indian and southeastern Atlantic Oceans: an assessment of their possible impact on cetaceans. Rep Int Whal Comm 15(Spec Issue):317-328

Connor RC, Mann J, Tyack PL, Whitehead H (1998) Social evolution in toothed whales. Trends Ecol Evol 13: 228-232

> Corsolini S, Ademollo N, Romeo T, Greco S, Focardi S (2005) Persistent organic pollutants in edible fish: a human and environmental health problem. Microchem J 79:115-123

Cox TM, Read A, Solow A, Tregenza N (2001) Will harbour porpoises (Phocoena phocoena) habituate to pingers? J Cetacean Res Manag 3:81-86

Cox TM, Read A, Swanner D, Urian K, Waples D (2003) Behavioral responses of bottlenose dolphins, Tursiops truncatus, to gillnets and acoustic alarms. Biol Conserv 115:203-212

> Cox TM, Lewison RL, Zydelis R, Crowder LB, Safina C, Read AJ (2007) Comparing effectiveness of experimental and implemented bycatch reduction measures: the ideal and the real. Conserv Biol 21:1155-1164

> Dawson SM, Read A, Slooten E (1998) Pingers, porpoises and power: uncertainties with using pingers to reduce bycatch of small cetaceans. Biol Conserv 84:141-146

Dawson SM, Northridge S, Waples D, Read AJ (2013) To ping or not to ping; the use of active acoustic devices in mitigating interactions between small cetaceans and gillnet fisheries. Endang Species Res 19:201-221

> DeLong R, Gilmartin WG, Simpson JG (1973) Premature births in California sea lions: association with high organochlorine pollutant residue levels. Science 181: 1168-1170

Dungan SZ (2011) Comparing the social structures of IndoPacific humpback dolphins (Sousa chinensis) from the Pearl River Estuary and eastern Taiwan Strait. MSc dissertation, Trent University, Peterborough, ON

Dungan SZ, Riehl KN, Wee A, Wang JY (2011) A review of the impacts of anthropogenic activities on the critically endangered eastern Taiwan Strait Indo-Pacific humpback dolphins. J Mar Anim Ecol 4:3-9

Fertl D, Leatherwood S (1997) Cetacean interactions with 
trawls: a preliminary review. J Northwest Atl Fish Sci 22: 219-248

Fisheries Agency (2010) Fisheries statistical yearbook-Taiwan, Kinmen and Matsu Area, 2009. Fisheries Agency, Taipei

Forney KA, Benson SR, Cameron GA (2001) Central California gillnet effort and bycatch of sensitive species, 1990-98. In: Melvin EF, Parrish JK (eds) Seabird bycatch: trends, roadblocks and solutions. AK-SG-01-01, University of Alaska Sea Grant, Fairbanks, AK, p 141-160

Forney KA, Kobayashi DR, Johnston DW, Marchetti JA, Marsik MG (2011) What's the catch? Patterns of cetacean bycatch and depredation in Hawaii-based pelagic longline fisheries. Mar Ecol 32:380-391

Foster EA, Franks DW, Mazzi S, Darden SK, Balcolm KC, Ford JKB, Croft DP (2012) Adaptive prolonged postreproductive life span in killer whales. Science 337:1313

Gallo-Reynoso JP (1994) Factors affecting the population status of Guadalupe fur seal, Arctocephalus townsendi (Merriam, 1897), at Isla de Guadalupe, Baja California, Mexico. PhD thesis, University of California, Santa Cruz, $\mathrm{CA}$

Garrison L (2007) Interactions between marine mammals and pelagic longline fishing gear in the US Atlantic Ocean between 1992 and 2004. Fish Bull 105:408-417

Gerrodette T, Rojas-Bracho L (2011) Estimating the success of protected areas for the vaquita, Phocoena sinus. Mar Mamm Sci 27:E101-E125

Gilman E, Brothers N, McPherson G, Dalzell P (2006) A review of cetacean interactions with longline gear. J Cetacean Res Manag 8:215-223

Gormley AM, Slooten E, Dawson SM, Barker RJ, Rayment W, du Fresne S, Bräger S (2012) First evidence that marine protected areas can work for marine mammals. J Appl Ecol 49:474-480

- Gribble NA, McPherson G, Lane B (1998) Effect of the Queensland Shark Control Program on non-target species: whale, dugong, turtle and dolphin: a review. Mar Freshw Res 49:645-651

Guinet C, Bouvier J (1995) Development of intentional stranding hunting techniques in killer whale (Orcinus orca) calves at Crozet Archipelago. Can J Zool 73:27-33

Harwood MB, Hembree D (1987) Incidental catch of small cetaceans in the offshore gillnet fishery in northern Australian waters: 1981-1985. Rep Int Whal Comm 37: 363-367

Haug T, Lindstrøm U, Nilssen KT (2002) Variations in minke whale (Balaenoptera acutorostrata) diet and body condition in response to ecosystem changes in the Barents Sea. Sarsia 87:409-422

Helle E, Olsson M, Jensen S (1976) PCB levels correlated with pathological changes in seal uteri. Ambio 5:261-263

> Hennen D (2006) Associations between the Alaska Steller sea lion decline and commercial fisheries. Ecol Appl 16: 704-717

Hung SK (2008) Habitat use of Indo-Pacific humpback dolphins (Sousa chinensis) in Hong Kong. PhD dissertation, University of Hong Kong, Hong Kong

IUCN (International Union for Conservation of Nature) Species Survival Commission (2001) IUCN Red List categories and criteria, Version 3.1. Available at: www.iucn redlist.org/technical-documents/categories-and-criteria (accessed 10 April 2013)

- Jaaman SA, Lay-Anyi Y, Pierce GJ (2009) The magnitude and sustainability of marine mammal by-catch in fish- eries in East Malaysia. J Mar Biol Assoc UK 89:907-920

Jackson JBC, Kirby MX, Berger WH, Bjorndal KA and others (2001) Historical overfishing and the recent collapse of coastal ecosystems. Science 293:629-637

> Jackson JA, Patenaude NJ, Carroll EL, Baker CS (2008) How few whales were there after whaling? Inference from contemporary mtDNA diversity. Mol Ecol 17: 236-251

Jefferson TA (2000) Population biology of the Indo-Pacific hump-backed dolphin in Hong Kong waters. Wildl Monogr 144:1-65

Jefferson TA, Curry BE (1994) A global review of porpoise (Cetacea, Phocoenidae) mortality in gillnets. Biol Conserv 67:167-183

Jefferson TA, Hung SK (2004) A review of the status of the Indo-Pacific humpback dolphin (Sousa chinensis) in Chinese waters. Aquat Mamm 30:149-158

Jefferson TA, Karczmarski L (2001) Sousa chinensis. Mamm Species 655:1-9

Jefferson TA, Hung SK, Lam PKS (2006) Strandings, mortality and morbidity of Indo-Pacific humpback dolphins in Hong Kong, with emphasis on the role of environmental contaminants. J Cetacean Res Manag 8:181-193

Jefferson TA, Hung SK, Robertson KM, Archer FI (2012) Life history of the Indo-Pacific humpback dolphin in the Pearl River Estuary, southern China. Mar Mamm Sci 28: 84-104

> Kaiser MJ, Bullimore B, Newman P, Lock K, Gilbert S (1996) Catches in 'ghost fishing' set nets. Mar Ecol Prog Ser 145: $11-16$

Kaiser MJ, Collie JS, Hall SJ, Jennings S, Poiner IR (2001) Impacts of fishing on marine benthic habitats. In: Abstracts of papers presented at the Conference on responsible fisheries in the marine ecosystem, Reykjavic, 1-4 Oct 2001. FAO Fisheries Rep No. 658

Kiszka J, Muir C, Poonian C, Cox TM and others (2008) Marine mammal bycatch in the Southwest Indian Ocean: review and need for a comprehensive status assessment. West Indian Ocean J Mar Sci 7:119-136

Kuiken T (1996) Review of the criteria for diagnosis of bycatch in cetaceans. In: Kuiken (ed) Proc 2nd ECS workshop on cetacean pathology, Montpellier, France, 2 March 1994. European Cetacean Society Newsletter 26 Spec Issue, p 38-43

> Larsen F, Eigaard O, Tougaard J (2007) Reduction of harbour porpoise (Phocoena phocoena) bycatch by ironoxide gillnets. Fish Res 85:270-278

- Lawler IF, Aldrich JC (1987) The sublethal effects of bis(tributyltin)oxide on Crassostrea gigas spat. Mar Pollut Bull 18:274-278

Leung CCM, Jefferson TA, Hung SK, Zheng GJ, Yeung LWY, Richardson BJ, Lam PKS (2005) Petroleum hydrocarbons, polycyclic aromatic hydrocarbons, organochlorine pesticides and polychorinated biphenyls in tissues of Indo-Pacific humpback dolphins from south China waters. Mar Pollut Bull 50:1713-1719

Lockyer C (1986) Body fat condition in Northeast Atlantic fin whales, Balaenoptera physalus, and its relationship with reproduction and food resource. Can J Fish Aquat Sci 43: 142-147

> Lusseau D (2003) The emergent properties of a dolphin social network. Proc Biol Sci 270:S186-S188

$>$ Lusseau D, Conradt L (2009) The emergence of unshared consensus decisions in bottlenose dolphins. Behav Ecol Sociobiol 63:1067-1077 
McAuliffe K, Whitehead H (2005) Eusociality, menopause and information in matrilineal whales. Trends Ecol Evol 20:650

Minh TB, Watanabe M, Nakata H, Tanabe S, Jefferson TA (1999) Contamination by persistent organochlorines in small cetaceans from Hong Kong coastal waters. Mar Pollut Bull 39:383-392

Mortensen P, Bergman A, Bignert A, Hansen HJ, Härkönen T, Olsson M (1992) Prevalence of skull lesions in harbor seals (Phoca vitulina) in Swedish and Danish museum collections: 1835-1988. Ambio 21:520-524

Nedelec C, Prado J (1990) Definition and classification of fishing gear categories. FAO Fish Tech Pap No. 222, Revision 1. Food and Agriculture Organization of the United Nations, Rome

NMFS (National Marine Fisheries Service) (2005) Revisions to guidelines for assessing marine mammal stocks. Available at: www.nmfs.noaa.gov/pr/pdfs/sars/gamms2005 (accessed 15 April 2013)

Parsons ECM (2004) The potential impacts of pollution on humpback dolphins, with a case study on the Hong Kong population. Aquat Mamm 30:18-37

> Parsons ECM, Jefferson TA (2000) Post-mortem investigations on stranded dolphins and porpoises from Hong Kong waters. J Wildl Dis 36:342-356

Pauly D, Christensen V, Guenette S, Pitcher TJ, Sumaila UR, Walters CJ (2002) Towards sustainability in world fisheries. Nature 418:689-695

Perrin WF (2009) Coloration. In: Perrin WF, Würsig B, Thewissen JGM (eds) Encyclopedia of marine mammals, 2nd edn. Elsevier, San Diego, CA, p 243-249

Perrin WF, Reilly SB (1984) Reproductive parameters of dolphins and small whales of the family Delphinidae. Rep Int Whal Comm 6(Spec Issue):97-133

Perrin WF, Donovan GP, Barlow J (1994) Gillnets and cetaceans. Rep Int Whal Comm Spec Issue 15

Perrin WF, Reeves RR, Dolar MLL, Jefferson TA, Marsh H, Wang JY, Estacion J (2005) Report of the 2nd workshop on the biology and conservation of small cetaceans and dugongs of Southeast Asia. CMS Technical Series Publication 9, UNEP/CMS Secretariat, Bonn

Pitcher TJ (2001) Fisheries managed to rebuild ecosystems? Reconstructing the past to salvage the future. Ecol Appl 11:601-617

Rayment W, Webster T (2009) Observations of Hector's dolphins (Cephalorhynchus hectori) associating with inshore trawling at Banks Peninsula, New Zealand. N Z J Mar Freshw Res 43:911-916

Read AJ (1990) Estimation of body condition in harbour porpoises, Phocoena phocoena. Can J Zool 68:1962-1966

Read AJ, Murray KT (2000) Gross evidence of humaninduced mortality in small cetaceans. NOAA Tech Memo NMFS-OPR-15, US Department of Commerce, Washington, DC

Read AJ, Drinker P, Northridge S (2006) Bycatch of marine mammals in US and global fisheries. Conserv Biol 20: 163-169

Reeves RR, Perrin WF, Taylor BL, Baker CS, Mesnick SL (2004) Report of the workshop on shortcomings of cetacean taxonomy in relation to needs of conservation and management. NOAA Tech Memo NMFS-SWFSC363, US Department of Commerce, San Diego, CA

Reeves RR, Dalebout ML, Jefferson TA, Karczmarski L and others (2008) Sousa chinensis (eastern Taiwan Strait subpopulation). In: IUCN Red List of Threatened Species.
Available at: www.iucnredlist.org (accessed 3 April 2013)

Reijnders PJH (1986) Reproductive failure in common seals feeding on fish from polluted coastal waters. Nature 324 : 456-457

Rendell L, Whitehead H (2001) Culture in whales and dolphins. Behav Brain Sci 24:309-382

> Rojas-Bracho L, Reeves RR, Jaramillo-Legorreta A (2006) Conservation of the vaquita Phocoena sinus. Mammal Rev 36:179-216

> Ross PS, De Swart RL, Van Loveren H, Osterhaus ADME, Vos JG (1996) The immunotoxicity of environmental contaminants to marine wildlife: a review. Annu Rev Fish Dis 6:151-165

Ross PS, Ellis GM, Ikonomou MG, Barrett-Lennard LG, Addison RF (2000) High PCB concentrations in freeranging Pacific killer whales, Orcinus orca: effects of age, sex, and dietary preference. Mar Pollut Bull 40: 504-515

> Ross PS, Dungan SZ, Hung SK, Jefferson TA and others (2010) Averting the baiji syndrome: conserving habitat for Critically Endangered dolphins in eastern Taiwan Strait. Aquat Conserv 20:685-694

Shane S, Wells R, Wursig B (1986) Ecology, behaviour and social organization of the bottlenose dolphin: a review. Mar Mamm Sci 2:34-63

Shephard S, Brophy D, Read DG (2010) Can bottom trawling indirectly diminish carrying capacity in a marine ecosystem? Mar Biol 157:2375-2381

Slooten E, Davies N (2012) Hector's dolphin risk assessments: Old and new analyses show consistent results. J R Soc N Z 42:49-60

Slooten E, Dawson SM (2008) Sustainable levels of human impact for Hector's dolphin. Open Conserv Biol J 2: $37-43$

Slooten E, Dawson SM (2010) Assessing the effectiveness of conservation management decisions: likely effects of new protection measures for Hector's dolphin. Aquat Conserv 20:334-347

Slooten E, Fletcher D, Taylor BL (2000) Accounting for uncertainty in risk assessment: case study of Hector's dolphin mortality due to gillnet entanglement. Conserv Biol 14:1264-1270

Smith GJD, Read AJ, Gaskin DE (1983) Incidental catch of harbor porpoise, Phocoena phocoena (L.), in herring weirs in Charlotte County, New Brunswick, Canada. Fish Bull 81:660-662

Stewart BS, Yochem PK, Huber HR, DeLong RL and others (1994) History and present status of the northern elephant seal population. In: Le Boeuf BJ, Laws RM (eds) Elephant seals. University of California Press, Los Angeles, CA, p 29-48

Takahashi S, Le LTH, Saeki H, Nakatani N, Tanabe S, Miyazaki N, Fujise Y (2000) Accumulation of butyltin compounds and total tin in marine mammals. Water Sci Technol 42:97-108

Taylor BL (1997) Defining 'population' to meet management objectives for marine mammals. In: Dizon AE, Chivers SJ, Perrin WF (eds) Molecular genetics of marine mammals. Mar Mamm Sci Spec Publ 33:49-65

Taylor BL, Dizon AE (1999) First policy then science: why a management unit based solely on genetic criteria can't work. Mol Ecol 8:S11-S16

Taylor BL, Wade PR, DeMaster DP, Barlow J (2000) Incorporating uncertainty into management models for marine mammals. Conserv Biol 14:1243-1252 
Taylor BL, Martien K, Morin P (2010) Identifying units to conserve using genetic data. In: Boyd IL, Bowen WD, Iverson SJ (eds) Marine mammal ecology and conservation - a handbook of techniques. Oxford University Press, Oxford, p 306-344

Thiele D (2010) Collision course: snubfin dolphin injuries in Roebuck Bay. WWF, Ultimo

Tillin HM, Hiddink JG, Jennings S, Kaiser MJ (2006) Chronic bottom trawling alters the functional composition of benthic invertebrate communities on a sea-basin scale. Mar Ecol Prog Ser 318:31-45

Trippel EA, Holy NL, Palka DL, Shepherd TD, Melvin GD, Terhune JM (2003) Nylon barium sulphate gillnet reduces porpoise and seabird mortality. Mar Mamm Sci 19:240-243

Trites AW, Donnelly CP (2003) The decline of Steller sea lions, Eumetopias jubatus, in Alaska: a review of the nutritional stress hypothesis. Mammal Rev 33:3-28

US Fish \& Wildlife Service (2003) Final revised recovery plan for the southern sea otter (Enhydra lutris nereis). US Fish and Wildlife Service, Portland, OR

- Van Waerebeek K, Barnett L, Camara A, Cham A and others (2004) Distribution, status, and biology of the Atlantic humpback dolphin, Sousa teuszii (Kukenthal, 1892). Aquat Mamm 30:56-83

Wade PR (1998) Calculating thresholds to the humancaused mortality of cetaceans and pinnipeds. Mar Mamm Sci 14:1-37

Wang JY (2009) Stock identity. In: Perrin WF, Würsig B, Thewissen JGM (eds) Encyclopedia of marine mammals, 2nd edn. Elsevier, San Diego, CA, p 1115-1118

Wang JY, Yang SC (2011) Evidence for year-round occurrence of the eastern Taiwan Strait Indo-Pacific humpback dolphins (Sousa chinensis) in the waters of western Taiwan. Mar Mamm Sci 27:652-658

Wang JY, Yang SC, Reeves RR (2004) Report of the first workshop on conservation and research needs of IndoPacific humpback dolphins, Sousa chinensis, in the waters of Taiwan. National Museum of Marine Biology and Aquarium, Checheng

- Wang JY, Yang SC, Hung SK, Jefferson TA (2007a) Distribution, abundance and conservation status of the eastern Taiwan Strait population of Indo-Pacific humpback dolphins, Sousa chinensis. Mammalia 71:157-165

Wang JY, Yang SC, Reeves RR (2007b) Report of the 2nd international workshop on conservation and research needs of the eastern Taiwan Strait population of IndoPacific humpback dolphins, Sousa chinensis. National Museum of Marine Biology and Aquarium, Checheng

Wang JY, Hung SK, Yang SC, Jefferson TA, Secchi ER (2008) Population differences in the pigmentation of

Editorial responsibility: Ana Cañadas,

Madrid, Spain
Indo-Pacific humpback dolphins, Sousa chinensis, in Chinese waters. Mammalia 72:302-308

> Wang JY, Yang SC, Fruet PF, Secchi ER (2012) Mark-recapture analyses of the Critically Endangered eastern Taiwan Strait population of Indo-Pacific humpback dolphins (Sousa chinensis): implications for conservation. Bull Mar Sci 88:885-902

Weir JS, Duprey NMT, Würsig B (2008) Dusky dolphin (Lagenorhynchus obscurus) subgroup distribution: Are shallow waters a refuge for nursery groups? Can J Zool 86:1225-1234

Wells RS, Allen JB, Hofman S, Bassos-Hull K and others (2008) Consequences of injuries on survival and reproduction of common bottlenose dolphins (Tursiops truncatus) along the west coast of Florida. Mar Mamm Sci 24: 774-794

> Werner T, Kraus S, Read A, Zollett E (2006) Fishing techniques to reduce the bycatch of threatened marine animals. Mar Technol Soc J 40:50-68

> Whitehead H, Rendell L, Osborne WH, Würsig B (2004) Culture and conservation of non-humans with reference to whales and dolphins: review and new directions. Biol Conserv 120:427-437

Williams R, Lusseau D (2006) A killer whale social network is vulnerable to targeted removals. Biol Lett 2: 497-500

Yang G, Zhou KY, Xu XR, Leatherwood S (1999) A survey on the incidental catches of small cetaceans in coastal waters of China. Chin J App Ecol 10:713-716

Yang G, Zhou KY, Xu XR (2000) Population density, distribution, and incidental catches of bottlenose dolphins in Xiamen-Dongshan waters of the Taiwan Strait. Acta Ecol Sin 20:1002-1008

Ylitalo GM, Stein JE, Hom T, Johnson LL and others (2005) The role of organochlorines in cancer-associated mortality in California sea lions (Zalophus californianus). Mar Pollut Bull 50:30-39

Young NM, Iudicello S (2007) Worldwide bycatch of cetaceans: an evaluation of the most significant threats to cetaceans, the affected species and the geographic areas of high risk, and the recommended actions from various independent institutions. NOAA Tech Memo NMFSOPR-36, Silver Spring, MD

Yurk H, Barrett-Lennard L, Ford JKB, Matkin CO (2002) Cultural transmission within maternal lineages: clans in resident killer whales. Anim Behav 63:1103-1119

Zhou KY, Wang XY (1994) Brief review of passive fishing gear and incidental catches of small cetaceans in Chinese waters. In: Perrin WF, Donovan GP, Barlow J (eds) Gillnets and cetaceans. Rep Int Whal Comm Spec Issue 15:347-354

Submitted: December 20, 2012; Accepted: May 16, 2013 Proofs received from author(s): September 12, 2013 